\title{
Heparin's anti-inflammatory effects require glucosamine 6-O-sulfation and are mediated by blockade of $L$ - and P-selectins
}

\author{
Lianchun Wang, ${ }^{1}$ Jillian R. Brown, ${ }^{1}$ Ajit Varki, ${ }^{1,2}$ and Jeffrey D. Esko ${ }^{1}$ \\ ${ }^{1}$ Department of Cellular and Molecular Medicine, and \\ ${ }^{2}$ Department of Medicine, and Glycobiology Research and Training Center, University of California, San Diego, \\ La Jolla, California, USA
}

\begin{abstract}
Heparin has been used clinically as an anticoagulant and antithrombotic agent for over 60 years. Here we show that the potent anti-inflammatory property of heparin results primarily from blockade of P-selectin and L-selectin. Unfractionated heparin and chemically modified analogs were tested as inhibitors of selectin binding to immobilized sialyl Lewis ${ }^{\mathrm{x}}$ and of cell adhesion to immobilized selectins or thrombin-activated endothelial cells. Compared with unfractionated heparin, the modified heparinoids had inhibitory activity in this general order: over- $O$-sulfated heparin > heparin > 2-O,3-O-desulfated $\geq \mathrm{N}$-desulfated/ $\mathrm{N}$-acetylated heparin $\geq$ carboxyl-reduced heparin $\geq \mathrm{N}-, 2-\mathrm{O}, 3-\mathrm{O}$ desulfated heparin >> 6-O-desulfated heparin. The heparinoids also showed similar differences in their ability to inhibit thioglycollate-induced peritonitis and oxazolone-induced delayed-type hypersensitivity. Mice deficient in P- or L-selectins showed impaired inflammation, which could be further reduced by heparin. However, heparin had no additional effect in mice deficient in both P-and L-selectins. We conclude that (a) heparin's anti-inflammatory effects are mainly mediated by blocking P- and L-selectin-initiated cell adhesion; (b) the sulfate groups at $\mathrm{C} 6$ on the glucosamine residues play a critical role in selectin inhibition; and (c) some non-anticoagulant forms of heparin retain anti-inflammatory activity. Such analogs may prove useful as therapeutically effective inhibitors of inflammation.
\end{abstract}

J. Clin. Invest. 110:127-136 (2002). doi:10.1172/JCI200214996.

\section{Introduction}

The recruitment of leukocytes from the blood and lymphatic systems into tissues facilitates a successful host response to tissue injury and pathogen invasion. When these processes go awry, they can contribute to the pathophysiology of acute and chronic inflammatory disease. Members of the selectin family of adhesion receptors $(\mathrm{E}, \mathrm{P}$, and $\mathrm{L})$ mediate the initial adhesive events that direct the movement of leukocytes across the endothelium in inflamed tissues (reviewed in refs. 1-9). All three selectins contain an amino-terminal, calciumdependent carbohydrate recognition domain that binds to carbohydrate ligands on cells. P-selectin is rapidly

Received for publication January 7, 2002, and accepted in revised form May 28, 2002.

Address correspondence to: Jeffrey D. Esko, Department of Cellular and Molecular Medicine, University of California, San Diego, 9500 Gilman Drive, La Jolla, California 92093-0687, USA. Phone: (858) 822-1100; Fax: (858) 534-5611;

E-mail: jesko@ucsd.edu.

Conflict of interest: No conflict of interest has been declared. Nonstandard abbreviations used: sialyl Lewis ${ }^{\mathrm{X}}\left(\mathrm{SLe}^{\mathrm{X}}\right)$; P-selectin glycoprotein ligand-1 (PSGL-1); glycosylationdependent cell adhesion molecule-1 (GlyCAM-1); $N$-desulfated/ $N$-acetylated heparin (NDS-heparin); oversulfated heparin (OS-heparin); carboxyl-reduced heparin (CR-heparin); 6-O-desulfated heparin (6DS-heparin); 2-O,3-O-desulfated heparin (2/3DS-heparin); $\mathrm{N}$-,2-O,3-O-desulfated heparin (N/2/3DS-heparin); polyacrylamide-SLe ${ }^{\mathrm{X}}\left(\mathrm{PAA}_{\mathrm{SL}} \mathrm{S}^{\mathrm{X}}\right)$; allergic contact dermatitis (ACD); delayed-type hypersensitivity (DTH); contact skin hypersensitivity (CSH). mobilized to the surface of endothelial cells or platelets exposed to thrombin or histamine, and L-selectin is expressed constitutively on circulating leukocytes. In contrast, agents such as IL- 1 , TNF- $\alpha$, and endotoxin induce E-selectin specifically in endothelial cells several hours after activation. P-selectin and L-selectin appear to mediate the initial events in cellular infiltration due to their rapid appearance on activated endothelium and constitutive expression on leukocytes, respectively.

All three selectins bind to sialylated, fucosylated carbohydrate antigens related to sialyl Lewis ${ }^{\mathrm{X}}$ [SLe $^{\mathrm{x}}$, Neu5Ac $\alpha 2,3$ Gal $\beta 1,4$ (Fuc $\alpha 1,3)$ GlcNAc $\beta-](10,11)$. SLe ${ }^{\mathrm{X}}$ determinants have been detected on specific selectin ligands, such as P-selectin glycoprotein ligand-1 (PSGL-1) and E-selectin ligand-1 (ESL-1), and on glycosylationdependent cell adhesion molecule-1 (GlyCAM-1). These interactions appear to involve sulfate residues either on the carbohydrate or on the protein as sulfated tyrosine residues in proximity to the carbohydrate chain (12). Genetic data from mutant mice and inborn errors in humans substantiate the requirement of the glycosylated ligand for selectin function in vivo (13-15).

Several studies have shown that heparin and heparan sulfate can be recognized by L-selectin and P-selectin (16). Heparin and heparin-like oligosaccharides can inhibit L-selectin or P-selectin binding to SLe ${ }^{\mathrm{X}}$-related compounds or to SLe ${ }^{\mathrm{x}}$ determinants on HL-60 cells at concentrations lower than those required for inhibition by SLe ${ }^{\mathrm{x}}$ itself (17-21). Injected heparin also affects the 
inflammatory response (22), causes leukocytosis (23-25), and attenuates tumor metastasis in mice by inhibiting P-selectin-mediated interactions of platelets with carcinoma cell-surface mucin ligands (26). These studies suggest that the anti-inflammatory effects of heparin are due to a blockade of $\mathrm{P}$ - and L-selectins, but direct evidence for this mode of action in vivo is lacking.

Heparin and heparan sulfate consist of repeating disaccharide units containing D-glucuronic acid (GlcA) or L-iduronic acid (IdoA) and a glucosamine residue that is either $N$-sulfated (GlcNS), $N$-acetylated (GlcNAc), or, occasionally, unsubstituted $\left(\mathrm{GlcNH}_{2}\right)$ (27). The disaccharides may be further sulfated at $\mathrm{C} 6$ or $\mathrm{C} 3$ of the glucosamine residues and $\mathrm{C} 2$ of the uronic acid residues. The potent anticoagulant activity of heparin depends on a specific arrangement of sulfated sugar units and uronic acid epimers, which form a binding site for antithrombin (27). Much less information is available about the specific oligosaccharide structures in heparin that interact with P- and L-selectins $(18,21,28)$. Thus, we also sought to understand the relationship of heparin fine structure to its interaction with these selectins.

In the present study, various chemically-modified heparin derivatives (heparinoids) were evaluated for their ability to block P-and L-selectin-dependent interactions with sialylated, fucosylated ligands in vitro and to block inflammation in mice. The results show that the inhibitory properties of heparin depend critically on 6-O-sulfated glucosamine residues. Furthermore, studies of selectin-deficient mice indicate that heparin interactions with P- and L-selectin can completely account for its anti-inflammatory activity in vivo. Together, the data indicate that non-anticoagulant forms of heparin that bind to P- or L-selectin may prove useful for treating inflammatory disease.

\section{Methods}

Heparin and its derivatives. Porcine intestinal heparin $\left(\mathrm{M}_{\mathrm{r}}=12,000-15,000\right)$ was kindly provided by Patrick Shaklee (Scientific Protein Laboratories Inc., Milwaukee, Wisconsin, USA). $N$-desulfated $/ N$-acetylated heparin (NDS-heparin) $(29,30)$, oversulfated heparin (OS-heparin) (31), and carboxyl-reduced heparin (CR-heparin) (32) were obtained from Glycomed Inc. (Alameda, California, USA). 2-O,3-O-desulfated heparin (2/3DS-heparin) was prepared according to the method of Fryer et al. (33). Completely 6-O-desulfated heparin (6DS-heparin) was produced by regioselective hydrolysis with $N$-methyl- $N$-(trimethylsilyl)trifluoroacetamide (34) and compared with a standard sample kindly provided by Yutaka Kariya (Seikagaku Corp., Tokyo, Japan). This preparation contained about $20 \%$ less 2-O-sulfate groups. The anticoagulant activity of heparin and modified heparinoids was analyzed by amidolytic anti-factor Xa assay (35). All samples tested negative for endotoxin using the Limulus test.

${ }^{13} \mathrm{C}$-NMR experiments were carried out at $80^{\circ} \mathrm{C}$ in $\mathrm{D}_{2} \mathrm{O}$ (sample volumes of $0.6-0.7 \mathrm{ml}$ in $5-\mathrm{mm}$ tubes; Wilmad Labglass, Buena, New Jersey, USA) on a Unity
Inova 500 spectrometer (Varian Inc., Walnut Creek, California, USA). A 5-mm broadband observe- ${ }^{1} \mathrm{H}$ decoupling probe was used for all experiments. A SUN Microsystems (Santa Clara, California, USA) 4/330 computer running Varian's VNMR software (version 4.1) controlled data acquisition. DEPT135 data sets were collected with the delay between pulses set to 3.6 ms corresponding to a $(\mathrm{C}-\mathrm{H})$ value of $140 \mathrm{~Hz}$, and the final proton pulse set to $135^{\circ}$ to distinguish $\mathrm{CH}_{2}$ from all other carbon signals. Selected NMR spectra for the chemically synthesized 6DS-heparin were interpreted by comparison of the chemical shifts with those obtained with standard heparin.

Disaccharide composition was determined by complete depolymerization of the chains by hydrazinolysis, nitrous acid cleavage, and borotritide reduction, followed by reverse-phase ion-pairing chromatography using a Hi-Chrom S5 ODS C18 column $(4.6 \times 50$ $\mathrm{mm}$; Regis Technologies Inc., Morton Grove, Illinois, USA) as reported previously (36). Individual peaks were identified by comparison with standard disaccharides from commercial heparin and with published results. As reported previously, complete 6-O-desulfation was accompanied by partial loss of 2-O-sulfate groups on uronic acids (34).

Mice. Wild-type, P-selectin-deficient $\left(\mathrm{P}^{-/-}\right)$, and L-selectin-deficient $\left(\mathrm{L}^{-/}\right)$mice bred on $\mathrm{C} 57 \mathrm{BL} / 6$ background (6-8 weeks old) were purchased from The Jackson Laboratory (Bar Harbor, Maine, USA). The combined P-selectin- and L-selectin-deficient mice $\left(\mathrm{PL}^{-/-}\right)$ were kindly provided by Richard O. Hynes (Massachusetts Institute of Technology, Cambridge, Massachusetts, USA) (37) and bred at the University of California, San Diego, in conformance with the university's guidelines for the care and use of laboratory animals. Mice were weaned at 3 weeks, maintained on a 12-hour light-dark cycle, and fed water and standard rodent chow ad libitum.

Binding assays. Inhibition of selectin-SLe ${ }^{\mathrm{x}}$ binding by the heparinoids was done by coating sterile polystyrene 96-well ELISA plates (Corning Inc., Corning, New York, USA) at $4^{\circ} \mathrm{C}$ overnight with $200 \mathrm{ng}$ of polyacrylamide-SLe ${ }^{\mathrm{x}}$ (PAA-SLex; Glycotech Corp., Rockville, Maryland, USA) in $100 \mu \mathrm{l}$ of $50 \mathrm{mM}$ sodium bicarbonate buffer, $\mathrm{pH}$ 9.5. Plates were blocked for 3 hours at $4^{\circ} \mathrm{C}$ with $200 \mu \mathrm{l} /$ well of assay buffer containing $20 \mathrm{mM} \mathrm{N}$-[2-hydroxyethyl] piperazine- $N^{\prime}$ [2-ethanesulfonic acid], pH 7.45, $125 \mathrm{mM} \mathrm{NaCl}, 2$ $\mathrm{mM} \mathrm{CaCl}_{2}, 2 \mathrm{mM} \mathrm{MgCl}_{2}$, and $1 \%$ protease-free BSA (Pentex; Miles Inc., Kankakee, Illinois, USA). Recombinant selectin-Ig chimeras were prepared as described previously (19) and were preincubated at $4^{\circ} \mathrm{C}$ for about 1 hour with peroxidase-conjugated goat anti-human IgG (1:1,000 dilution in assay buffer; Jackson ImmunoResearch Laboratories Inc., West Grove, Pennsylvania, USA). The final selectin-Ig concentrations were $2.7,1.9$, and $5.0 \mu \mathrm{g} / \mathrm{ml}$ for E-, L-, and $\mathrm{P}$-selectin, respectively. The selectin- $\mathrm{Ig} /$ secondary antibody stock was aliquoted into tubes containing 
heparin/analog, buffer (positive control), $10 \mathrm{mM}$ sodium EDTA (negative control), anti-P-selectin, or anti-E-selectin adhesion-blocking $\mathrm{mAb}(1 \mu \mathrm{g}$; Pharmingen, San Diego, California, USA). The solutions $(100 \mu \mathrm{l})$ were preincubated at $4^{\circ} \mathrm{C}$ for $30 \mathrm{~min}$ utes and added to ELISA plates. After 4 hours at $4^{\circ} \mathrm{C}$, the plates were washed three times, followed by development with $2 \mu \mathrm{g} / \mathrm{ml} O$-phenylenediamine dihydrochloride, $50 \mathrm{mM}$ sodium citrate/sodium phosphate buffer, $\mathrm{pH} 5.2$, and $0.03 \% \mathrm{H}_{2} \mathrm{O}_{2}$. After 10 minutes, the peroxidase reaction was quenched by adding $50 \mu \mathrm{l}$ of $4 \mathrm{M} \mathrm{H}_{2} \mathrm{SO}_{4}$. The absorbance at 492 $\mathrm{nm}$ was recorded using a microplate reader (Molecular Devices Inc., Menlo Park, California, USA) equipped with SOFTmax software (Molecular Devices Inc.). All the raw data were converted into percentages for comparative purposes using the formula: $\%$ of maximum $=[$ (average of duplicates $)-($ negative control) $] /[$ (positive control) - (negative control) $] \times 100$.

$U 937$ cell binding to immobilized $E$-, L-, or P-selectin. The ability of heparin and the modified heparins to inhibit the adhesion of U937 cells to immobilized P-, L-, or E-selectins was examined by coating each well of a 96well ELISA plate at $4^{\circ} \mathrm{C}$ overnight with $8 \mu \mathrm{g} / \mathrm{ml}$ of Protein A (Sigma-Aldrich, St. Louis, Missouri, USA) in 50 $\mathrm{mM}$ carbonate buffer, $\mathrm{pH}$ 9.4. After blocking the plate with $1 \%$ BSA in PBS, P-selectin $(1 \mu \mathrm{g} /$ well $)$, L-selectin $(5 \mu \mathrm{g} /$ well $)$, or E-selectin $(1 \mu \mathrm{g} /$ well $)$ chimeras were added. After 1 hour, the wells were washed with blocking solution. U937 cells (CRL 1593.2; American Type Culture Collection, Rockville, Maryland, USA), were grown in RPMI-1640 medium (GIBCO BRL; Life Technologies Inc., Grand Island, New York, USA) containing $10 \% \mathrm{FBS}, 100 \mathrm{U} / \mathrm{ml}$ penicillin, and $100 \mu \mathrm{g} / \mathrm{ml}$ streptomycin in an atmosphere of $5 \% \mathrm{CO}_{2}$ in air and $100 \%$ relative humidity. The cells were fluorescently labeled with $10 \mu \mathrm{M}$ Calcein AM (Molecular Probes Inc., Eugene, Oregon, USA) in RPMI-1640 medium containing $2.5 \% \mathrm{FBS}$ for 30 minutes at $37^{\circ} \mathrm{C}$. The cells were collected by low-speed centrifugation, washed three times with RPMI-1640 medium, and resuspended at a density of $2 \times 10^{6}$ cells $/ \mathrm{ml}$ in medium without FBS. Heparin and heparin analogs, or $10 \mathrm{mM}$ sodium EDTA, anti-P-selectin, or anti-E-selectin adhesionblocking $\mathrm{mAb}(1 \mu \mathrm{g})$ in ELISA buffer, were added at 50 $\mu \mathrm{l} /$ well, and then the fluorescently labeled U937 cell suspension $(50 \mu \mathrm{l} /$ well $)$ was added and incubated for 30 minutes at room temperature. Nonadherent cells were removed by rinsing the plates three times with PBS, and the number of adherent cells was quantified by measuring the fluorescence intensity (CytoFluor II; PerSeptive Biosystems, Framingham, Massachusetts, USA; excitation wavelength at $485 \mathrm{~nm}$ ) after lysis of the cells with $2 \%$ Triton X-100 in $0.1 \mathrm{M}$ Tris- $\mathrm{HCl}, \mathrm{pH}$ 9.5. All the raw data were converted to relative fluorescence intensity for comparative purposes, using the formula given above for the ELISA.

Adherence to thrombin-stimulated human lung microvascular endothelial cells. P-selectin-mediated U937 cell adhe- sion to human lung microvascular endothelial cells was measured as described previously (38). Cryopreserved human lung microvascular endothelial cells at passage 4-6 were maintained in complete medium (EGM-2-MV Bullet Kit; BioWhittaker Inc., Walkersville, Maryland, USA) at $37^{\circ} \mathrm{C}$ under an atmosphere of $5 \% \mathrm{CO}_{2}$ and $100 \%$ relative humidity. The cells were seeded into $96-$ well flat-bottom cell culture plates at $2 \times 10^{4}$ cells per well, and a confluent monolayer was obtained within 2 days. The cells were then stimulated by adding 10 units per $\mathrm{ml}$ of human thrombin (Sigma-Aldrich) for 20 minutes. After washing once with warm RPMI-1640 medium, serially diluted heparin and analogs, $10 \mathrm{mM}$ sodium EDTA, or anti-P-selectin adhesion-blocking $\mathrm{mAb}(1 \mu \mathrm{g})$ were added $(50 \mu \mathrm{l} /$ well $)$. Control cells were incubated in ELISA assay buffer alone. U937 cells were fluorescently labeled as described above and added in $50 \mu \mathrm{l}$ of ELISA buffer $\left(10^{5}\right.$ per well $)$ containing the heparinoids. After 20 minutes at room temperature, the wells were gently washed three times with PBS. Bound U937 cells were quantified by measuring the relative fluorescence intensity as described above.

Thioglycollate-induced peritoneal inflammation. Mice were injected intraperitoneally with $2 \mathrm{ml}$ of $3 \%$ thioglycollate broth (lot no. 54H4607; Sigma-Aldrich) or sterile pyrogen-free saline (GIBCO BRL; Life Technologies Inc.). Five minutes later, the animals received intravenous injections of $0.2 \mathrm{ml}$ sterile pyrogen-free saline with and without heparin or analogs (0.5 or 1.25 $\mathrm{mg} /$ mouse). Mice were sacrificed after 3 hours, and the peritoneal cavities were lavaged with $8 \mathrm{ml}$ of ice-cold PBS containing $3 \mathrm{mM}$ EDTA to prevent clotting. Peritoneal cells were counted (Coulter Counter; Coulter Corp., Miami, Florida, USA). The cells were also stained for 30 minutes at $4^{\circ} \mathrm{C}$ with FITC-conjugated rat anti-mouse Gr-1 mAb (Pharmingen) diluted in PBS containing $2.5 \%$ FBS. After washing them three times with PBS, we counted the neutrophils on FACScan (Becton Dickinson Immunocytometry Systems, San Jose, California, USA) by gating the cells expressing a high level of Gr-1 antigen (39).

Allergic (delayed-type hypersensitivity) contact dermatitis. Groups of five to eight animals per experimental set were sensitized with $100 \mu \mathrm{l}$ of $2 \%$ oxazolone dissolved in acetone/olive oil $(4: 1, \mathrm{vol} / \mathrm{vol})$ applied topically to the shaved abdominal skin. Allergic contact dermatitis (ACD), a form of delayed-type hypersensitivity (DTH), was elicited 5 days later by challenging the mice with 20 $\mu \mathrm{l}$ of $2 \%$ oxazolone in acetone/olive oil, administered topically to each side of the right ear $(10 \mu \mathrm{l})$. The vehicle was applied in the same manner to each side of the left ear as a control. The thickness of the ear was measured before and 24 hours after challenge using a Mitutoyo engineer's micrometer (Mitutoyo Corp., Auburn, Illinois, USA). The ACD reaction is presented as the increment of ear swelling after challenge expressed as the mean \pm SE. The heparinoids $(1 \mathrm{mg} /$ mouse in $100 \mu \mathrm{l}$ saline) were administrated by intravenous injection within 30 minutes after antigen challenge. 


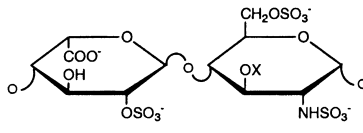

Heparin

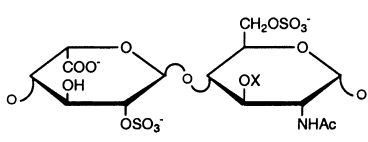

NDS-heparin

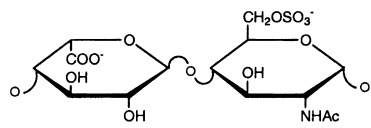

N/2/3DS-heparin

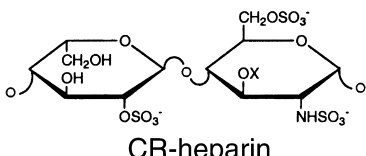

CR-heparin

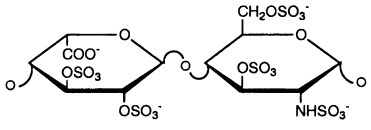

OS-heparin

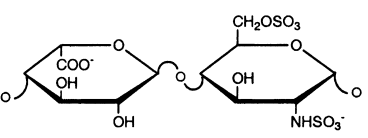

2/3DS-heparin

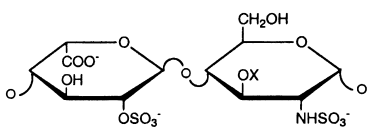

6DS-heparin
Figure 1

Representative disaccharide units of heparin and the various heparinoids. Each disaccharide illustrates a characteristic unit in the indicated preparation and does not represent the overall structure of the chains. $\mathrm{X}=\mathrm{H}$ or $\mathrm{SO}_{3}{ }^{-}$.

\section{Results}

The inhibitory effects of intact and chemically modified heparin

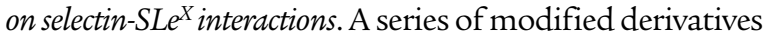
was prepared, including CR-heparin, OS-heparin, NDSheparin, 2/3DS-heparin, $N$-,2-O,3-O-desulfated heparin (N/2/3DS-heparin), and 6DS-heparin. Representative disaccharides of each type of heparinoid are given in Figure 1. Interaction with each selectin was inferred by measuring the ability of the heparinoids to block binding of L-, P-, and E-selectin-Ig chimeras to immobilized PAA-SLe ${ }^{X}$ (Figure 2). Heparin inhibited the binding of $\mathrm{L}$ - and P-selectin-Ig chimera to PAA-SLe ${ }^{\mathrm{X}}$ but had no effect on E-selectin-Ig, in accordance with previous findings $(18,19,21)$. Inhibition occurred across a wide concentration range, which likely reflects the structural heterogeneity inherently present in heparin (40). The residual binding at high concentrations was comparable to the level observed in the presence of $5 \mathrm{mM}$ EDTA or with blocking antibodies to the selectins ( $~ 90 \%$ inhibition), indicating that it is nonspecific.

The various heparinoids differed significantly in their potency. Analysis of dose-response curves for native heparin yielded IC $_{50}$ values of 0.1 and $2.5 \mu \mathrm{g} / \mathrm{ml}$ for blocking L- and P-selectins, respectively. OS-heparin was more potent $\left(\mathrm{IC}_{50}\right.$ values of 0.01 and $1.8 \mu \mathrm{g} / \mathrm{ml}$, respectively), whereas $6 \mathrm{DS}$-heparin was least effective (IC $\mathrm{IC}_{50}$ values of 85 and $450 \mu \mathrm{g} / \mathrm{ml}$, respectively). The other heparinoids gave intermediate levels of inhibition (Figure 2 and Table 1). Removal of the $\mathrm{N}-, 2-\mathrm{O}$ - and 3-O-linked sulfate groups or reduction of the carboxyl groups had the least effect. In general, higher concentrations were needed to inhibit P-selectin than to inhibit L-selectin, presumably reflecting the difference in affinity of the chimeras for clustered SLe ${ }^{\mathrm{X}}$ presented on the polyacrylamide resin.

Heparin inbibits adhesion of U937 cells. U937 cells express PSGL-1 (41), a natural ligand for P-selectin and L-selectin. As shown in Figure 3a, the various heparinoids also blocked adhesion of the cells to immobilized L-selectin in a concentration-dependent manner. Similar results were obtained with immobilized P-selectin (Figure 3b), but the compounds had no effect on cell adhesion to E-selectin (Figure 3c). The relative inhibitory efficacy of the heparinoids was similar to that observed in the competition assays (Figure 2), with OS-heparin exhibiting increased inhibitory activity compared with native heparin, and 6DS-heparin showing the lowest activity. In general, cell adhesion to P-selectin mediated by PSGL-1 on U937 cells was more sensitive to heparin inhibition

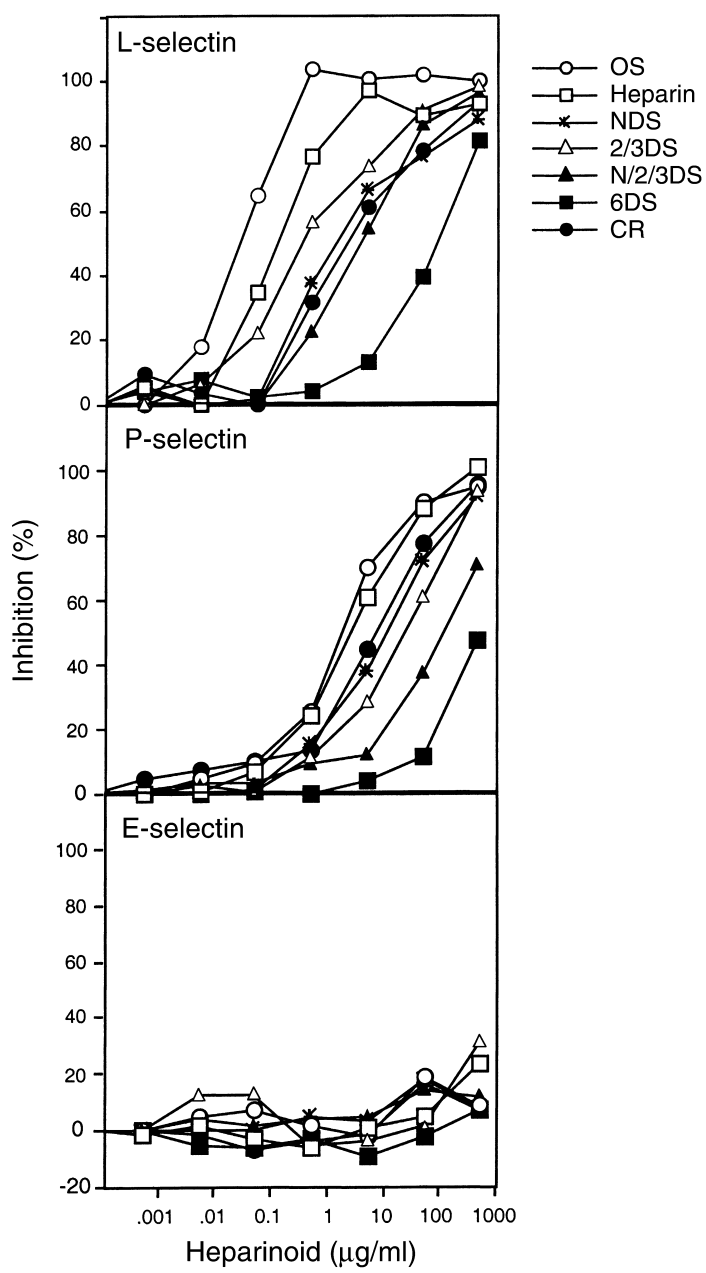

Figure 2

Inhibition of selectin-Ig binding to immobilized PAA-SLe ${ }^{x}$. Inhibition curves were generated using OS-heparin (open circles), heparin (open squares), NDS-heparin (asterisks), 2/3DS-heparin (open triangles), $\mathrm{N} / 2 / 3 \mathrm{DS}$-heparin (filled triangles), 6DS-heparin (filled squares), and CR-heparin (filled circles) (see Methods). Inclusion of a mAb to P-selectin, E-selectin, or EDTA blocked binding by more than $90 \%$. Each point represents the average of duplicate determinations, and the data are representative of three or four separate experiments. 
Table 1

Anticoagulant activities and inhibitory properties of heparin and its derivatives

\begin{tabular}{|c|c|c|c|c|c|c|}
\hline \multirow[t]{2}{*}{ Heparinoids } & \multirow[t]{2}{*}{$\begin{array}{c}\text { Anti-Xa } \\
\text { activity } \\
(\text { Units } / \mathrm{mg})^{\mathrm{A}}\end{array}$} & \multicolumn{2}{|c|}{$\begin{array}{c}\text { Inhibition of } \\
\text { Selectin-PAA-sLe }{ }^{\times} \text {Binding } \\
\left(I C_{50}, \mu \mathrm{g} / \mathrm{ml}\right)^{B}\end{array}$} & \multicolumn{2}{|c|}{$\begin{array}{l}\text { Inhibition of } \\
\text { Cell-Selectin Adhesion } \\
\left(\mathrm{IC}_{50}, \mu \mathrm{g} / \mathrm{ml}\right)^{\mathrm{C}}\end{array}$} & \multirow[t]{2}{*}{$\begin{array}{l}\text { Inhibition of } \\
\text { Cell-Cell Adhesion } \\
\left(\mathrm{IC}_{50}, \mu \mathrm{g} / \mathrm{ml}\right)^{\mathrm{D}}\end{array}$} \\
\hline & & L-selectin & P-selectin & L-selectin & P-selectin & \\
\hline Heparin & 149 & 0.1 & 2.5 & 0.4 & 0.3 & 0.5 \\
\hline Over-O-sulfated heparin (OS) & 12.5 & 0.01 & 1.8 & 0.1 & 0.02 & 0.08 \\
\hline 2-O,3-O desulfated heparin (2/3DS) & 1.7 & 0.4 & 20 & 3 & 4 & 2 \\
\hline $\mathrm{N}$-desulfated/N-acetylated heparin (NDS) & 0.1 & 1 & 10 & 0.7 & 0.9 & 25 \\
\hline $\mathrm{N}$-, 2-,3-O-desulfated heparin (N/2/3DS) & 0.1 & 4 & 100 & 5 & 8 & 50 \\
\hline 6-O-desulfated heparin (6DS) & 0.1 & 85 & 450 & 25 & 30 & 350 \\
\hline Carboxyl reduced heparin (CR) & 0.1 & 2 & 10 & 3 & 8 & 50 \\
\hline
\end{tabular}

AThe anticoagulant activity of heparin and its chemically modified derivatives was analyzed by aminolytic anti-factor Xa assay, as described in Methods. BThe $I C_{50}$ values for inhibition of selectin-PAA-sLex binding was determined from the data presented in Figure 2. The $I C_{50}$ values for inhibition of binding to E-selectin were over $500 \mu \mathrm{g} / \mathrm{ml}$. ${ }^{C}$ The IC $\mathrm{C}_{50}$ values inhibition of $\mathrm{U} 937$ cell adhesion to immobilized selectins were determined from the data presented in Figure 3 . The IC 50 values for inhibition of adhesion to E-selectin were over $500 \mu \mathrm{g} / \mathrm{ml}$. DThe IC $C_{50}$ values inhibition of U937 cell adhesion to thrombin activated endothelial cells were determined from the data presented in Figure 4.

than was binding of the selectin to PAA-SLe ${ }^{\mathrm{x}}$, which may reflect differences in the density or arrangement of these ligands.

Since selectins normally mediate cell-cell contact, we also examined the effect of the heparinoids on adhesion of U937 cells to cultured human lung microvascular endothelial cells (Figure 4). P-selectin expression was induced by brief incubation with human thrombin (42), which increased the level of adhesion of U937 cells approximately threefold over the control. Inclusion of a mAb to P-selectin or EDTA blocked adhesion of U937 cells to thrombin-activated endothelia by about $90 \%$. Overall, the pattern of inhibition of P-selectin-dependent cell-cell adhesion by the various heparinoids was similar to that described in the selectin-ligand and cellselectin assays (Figures 2 and 3). OS-heparin and 2/3DS-heparin were much more potent than the other heparinoids, giving $\mathrm{IC}_{50}$ values within a factor of 5 of native heparin (Table 1). Again, 6DS-heparin was least effective $\left(\mathrm{IC}_{50} \sim 350 \mu \mathrm{g} / \mathrm{ml}\right.$ ).

Structural analysis of $6 D S$-heparin. As the three assay systems demonstrated a critical role for the 6-O-sulfate group in the interaction with L- and P-selectin, detailed analytical studies of this preparation were done. ${ }^{13} \mathrm{C}-\mathrm{NMR}$ spectra of native heparin and 6DS-heparin (Figure 5, a and b, respectively) showed characteristic peaks at $69.4 \mathrm{ppm}$ for sulfate esters at $\mathrm{C} 6$ of GlcNAc and $\mathrm{GlcNSO}_{3}$ residues and $62.6 \mathrm{ppm}$ for residues unsubstituted at C6. In the heparin spectrum, the relative peak intensities suggested that about $85 \%$ of the glucosamine residues were 6 -O-sulfated and about $15 \%$ were unsulfated. In contrast, 6 DS-heparin had no peak

\section{Figure 3}

Effects of heparinoids on selectin-dependent cell adhesion. Adhesion of $U 937$ cells to immobilized selectin-Ig chimeras was measured (see Methods). Inclusion of a mAb to P-selectin, E-selectin, or EDTA blocked binding by more than $90 \%$. Each point represents the average of duplicate determinations, and the data are representative of three or four separate experiments. at $69.4 \mathrm{ppm}$, and a dramatic increase in signal at 62.6 $\mathrm{ppm}$. By these criteria, chemical removal of the 6-O-sulfate groups appeared to be nearly quantitative.

To confirm these findings chemically, the disaccharide composition of heparin and 6DS-heparin was determined. The preparations were $N$-deacetylated by

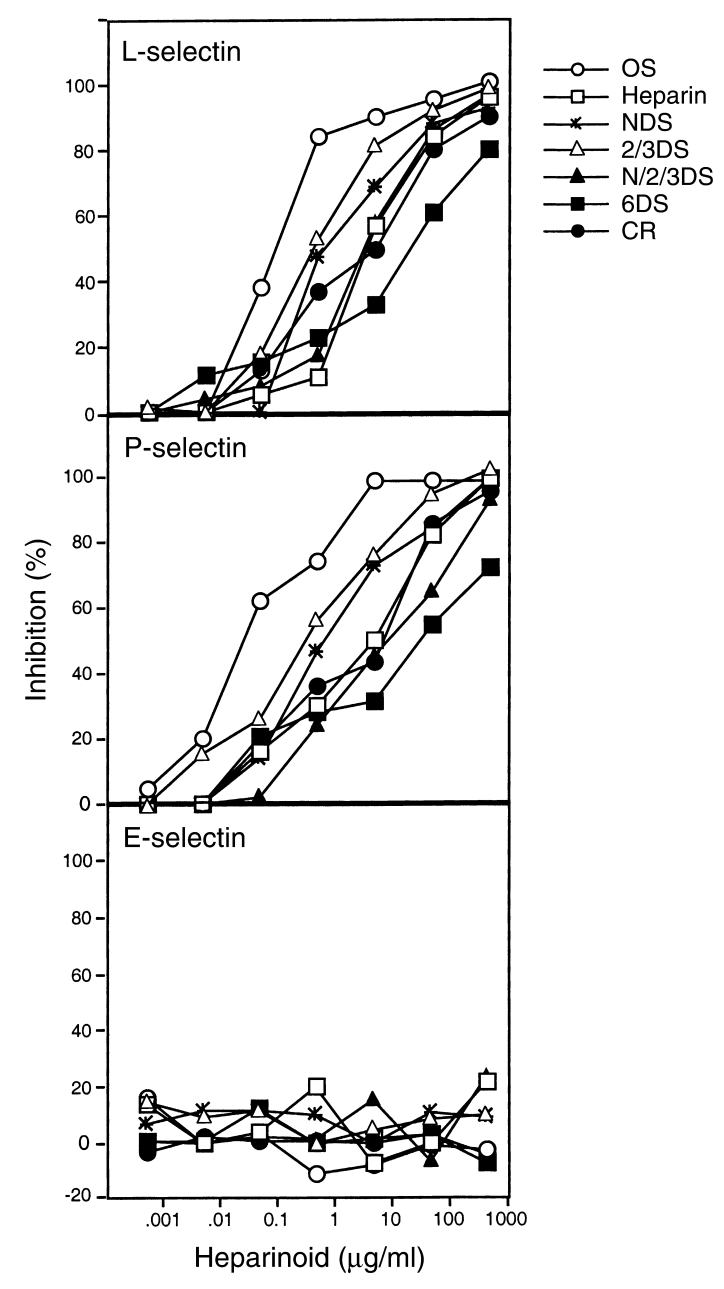




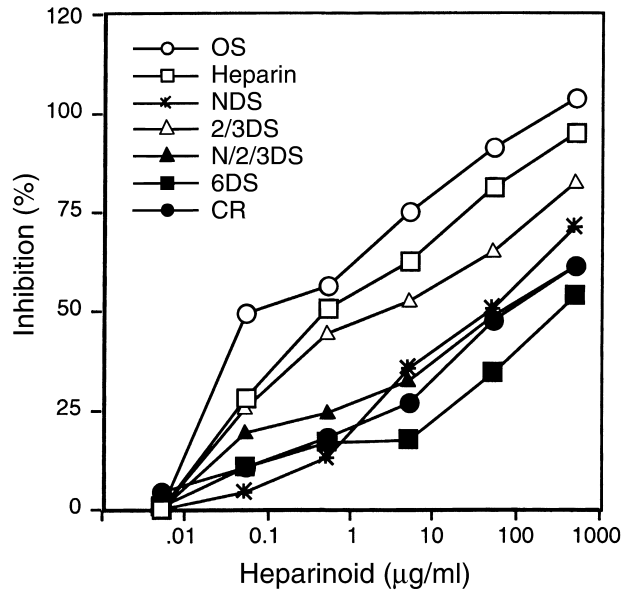

Figure 4

Inhibition of $U 937$ cell adhesion to activated human lung microvascular endothelial cells by modified heparins. Inclusion of a mAb to P-selectin or EDTA blocked binding by more than $90 \%$. Each point represents the average of duplicate determinations, and the data are representative of three or four separate experiments.

hydrazinolysis and completely depolymerized to disaccharides by treatment with nitrous acid at $\mathrm{pH} 4$ and 1.5. The liberated disaccharides were reduced with $\mathrm{NaB}\left[{ }^{3} \mathrm{H}\right]_{4}$ and analyzed by reverse-phase ion-pairing chromatography (36), which separates nonsulfated, monosulfated, and disulfated disaccharides with characteristic elution positions (Figure $5, \mathrm{~b}$ and $\mathrm{d}$ ). The major peak (peak 6) represents the fully sulfated disaccharide characteristic of heparin (Figure 1 ) and was derived from $\mathrm{IdoA} 2 \mathrm{OSO}_{3}-\mathrm{GlcNAc} / \mathrm{SO}_{3}\left(6 \mathrm{OSO}_{3}\right)$ units in the chain. Other 6-O-sulfated disaccharides were derived from IdoA-GlcNAc/ $\mathrm{SO}_{3}\left(6 \mathrm{OSO}_{3}\right)$ (peak 4), GlcA-GlcNAc/ $/ \mathrm{SO}_{3}\left(6 \mathrm{OSO}_{3}\right)$ (peak 5), and $\mathrm{GlcA} 2 \mathrm{OSO}_{3}$ $\mathrm{GlcNAc} / \mathrm{SO}_{3}\left(6 \mathrm{OSO}_{3}\right)$ (peak 7). Profiles of disaccharides from 6DS-heparin showed complete loss of these 6-O-sulfated units, accompanied by a dramatic increase of nonsulfated disaccharides (peak 1, representing a mixture of disaccharides derived from
IdoA-GlcNAc/SO 3 and GlcA-GlcNAc/SO 3 ). Based on these data, the extent of 6-O-desulfation was estimated to be greater than $99 \%$ with a concomitant loss of about $20 \%$ of the 2 -O-sulfate groups, as observed previously (34). Since extensive 2-O-desulfation in 2DSheparin (estimated at $>95 \%$ by disaccharide analysis) had much less effect on selectin-mediated binding and adhesion events (Figures 2-4), the dramatic decrease in inhibitory activity of 6DS-heparin was primarily due to removal of 6-O-sulfate groups.

Inbibition of thioglycollate-induced acute peritoneal inflammation. One caveat of the adhesion assays described in Figures 3 and 4 is that cell attachment was performed under static conditions as opposed to conditions of shear flow that would be encountered in the circulation. To examine the physiological relevance of the results, we explored the effects of the heparin derivatives in vivo in two inflammatory models. Thioglycollate injection into the mouse peritoneal cavity induces acute inflammation and neutrophil infiltration that is dependent on both L- and P-selectin (18, 37, 43-45). In control experiments, thioglycollate induced an approximately 120 -fold increase of Gr-1-positive neutrophils in the peritoneal cavity after 3 hours compared with the saline-injected animals $\left(1.3 \times 10^{6} \mathrm{per}\right.$ mouse versus $1 \times 10^{4}$ per mouse, respectively). To test the inhibitory effects of the various heparin preparations, the compounds were injected intravenously at dosages of 0.5 and $1.25 \mathrm{mg}$ per mouse, 5 minutes after thioglycollate injection. At low dosage, OS-heparin and native heparin inhibited neutrophil recruitment into the peritoneal cavity by $98 \%$ and $89 \%$, respectively, compared with saline (Figure 6a; $P<0.001$ ). All of the undersulfated heparins were ineffective at the 0.5 $\mathrm{mg}$ dose. When the dosage was increased to $1.25 \mathrm{mg}$ per mouse, 2/3DS-heparin, NDS-heparin, N/2/3DSheparin, and CR-heparin showed $50-60 \%$ inhibition $(P<0.05)$, but 6DS-heparin lacked activity even at the higher dose (Figure 6a). All of the desulfated preparations and CR-heparin had greatly reduced anticoagulant activity as measured by factor Xa attenuation by

\section{Figure 5}

Analysis of heparin and 6DS-heparin. Samples of heparin and 6DS-heparin were analyzed by ${ }^{13} \mathrm{C}-\mathrm{NMR}$ ( $\mathbf{a}$ and $\mathbf{b}$ ) and nitrous acid degradation to disaccharides ( $\mathbf{c}$ and $\mathbf{d}$ ) (see Methods). ( $\mathbf{a}$ and $\mathbf{b}$ ) The positions of peaks 1 and 2 correspond to $\mathrm{C} 6$ of 6-O-sulfated and unsubstituted glucosamine units, respectively. (c and d) Disaccharides generated by nitrous acid deamination of heparin and 6DS-heparin, respectively. 1, $\mathrm{aMan}_{\mathrm{R}}$ (anhydromannitol), GlcA-aMan $\mathrm{R}$, and IdoA$\mathrm{aMan}_{\mathrm{R}} ; 2$, IdoA-(2OSO$)_{3}-\mathrm{aMan}_{\mathrm{R}} ; 3, \mathrm{GlcA}\left(2 \mathrm{OSO}_{3}\right)$ $\mathrm{aMan}_{\mathrm{R}}$ and GlcA-aMan $\left(6 \mathrm{OSO}_{3}\right) ;$ 4, IdoA$\mathrm{aMan}_{\mathrm{R}}\left(6 \mathrm{OSO}_{3}\right) ; 5$, GlcA-aMan $\mathrm{R}\left(3 \mathrm{OSO}_{3}\right)\left(6 \mathrm{OSO}_{3}\right) ; 6$, $\operatorname{IdoA}\left(2 \mathrm{OSO}_{3}\right)-\mathrm{aMan}_{\mathrm{R}}\left(6 \mathrm{OSO}_{3}\right) ; \quad 7, \quad \mathrm{GlcA}\left(2 \mathrm{OSO}_{3}\right)$ $\operatorname{aMan}_{\mathrm{R}}\left(6 \mathrm{OSO}_{3}\right)$.
}
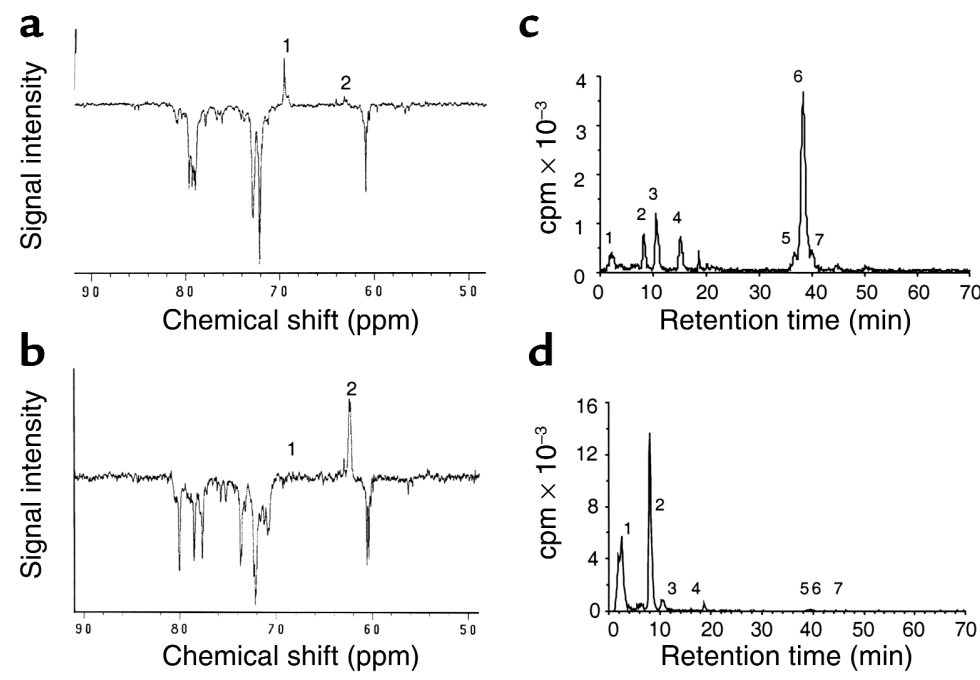

d

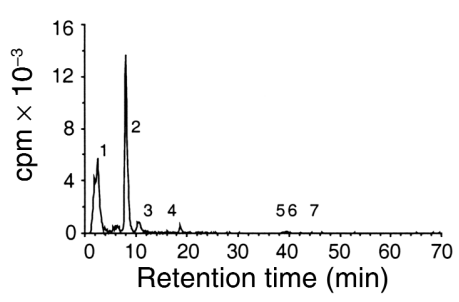




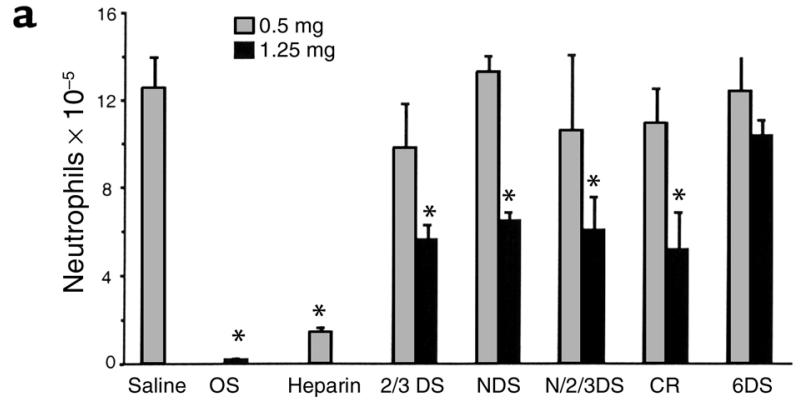

b

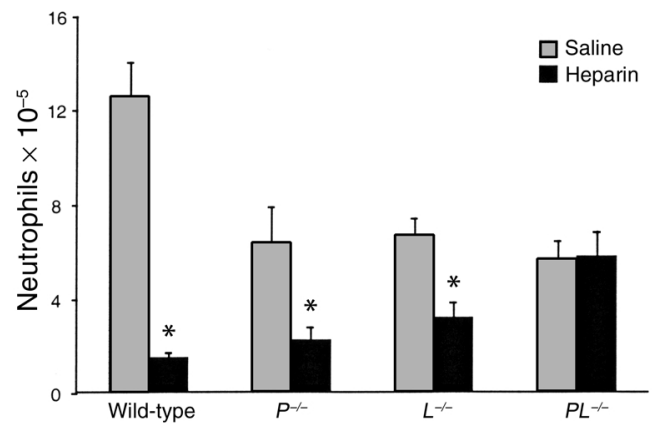

Figure 6

Inhibition of thioglycollate-induced peritoneal inflammation. (a) Heparin and the various analogs at 0.5 (gray bars) or $1.25 \mathrm{mg}$ per mouse (black bars) were injected intravenously 5 minutes after thioglycollate was injected intraperitoneally. The number of Gr-1-positive granulocytes in the peritoneal cavity was quantitated after 3 hours (see Methods). *Significant difference in neutrophil counts in the control mice that received standard heparin versus those injected with the indicated heparin derivatives. (b) Wild-type C57BL/ 6 and selectindeficient mice were injected with heparin $(0.5 \mathrm{mg})$ and thioglycollate. * Significant difference in neutrophil counts in mice treated with heparin (black bars) versus control mice that received only saline (gray bars). Each bar represents the average value \pm SD; $n=5-10$.

antithrombin (Table 1). Thus, the heparinoids could be administered at high dosage to achieve anti-inflammatory effects without unwanted bleeding.

To address whether the inhibition of peritonitis by heparin was L- and P-selectin-dependent, inhibition studies were performed in L-selectin- and Pselectin-deficient mice. Compared with that of wildtype mice, neutrophil recruitment into the peritoneal cavity in $\mathrm{L}^{-/-}$and $\mathrm{P}^{-/-}$mice was reduced by about $50 \%$ (Figure 6b). The $\mathrm{PL}^{-/-}$mice also exhibited reduced infiltration, but the level was not lower than observed in each single deficient strain, in contrast to previous findings (37). Possible explanations for the higher background level of leukocyte recruitment in $\mathrm{PL}^{-/}$mice include (a) the existence of P- and L-selectin-independent pathways that are upregulated due to the simultaneous deletion of both selectins, (b) underlying leukocytosis, and (c) differences in the source of mice: the $\mathrm{P}^{-/-}$and $\mathrm{L}^{-/-}$mice were obtained from The Jackson Laboratory, whereas the $\mathrm{PL}^{-/-}$mice were bred on site and possibly may have some base-line level of chronic inflammation that had upregulated other cell adhesion pathways. Regardless of the reason, the higher level of infiltration makes the lack of effect by injected heparin even more dramatic. Heparin $(0.5 \mathrm{mg} /$ mouse) further inhibited the accumulation of neutrophils in both $\mathrm{L}^{-/}$ and $\mathrm{P}^{-/}$mice but had no effect on infiltration observed in the doubly deficient $\mathrm{PL}^{-/}$mice. The lack of additive effects in the heparin-treated, doubly deficient mice confirmed that thioglycollate-induced peritonitis was both P- and L-selectin-dependent, and that the antiinflammatory effect of the heparinoids was mediated primarily by blocking these receptors.

Inbibition of DTH contact dermatitis by heparinoids. To determine whether the inhibitory effect of heparin in the peritonitis model could be generalized to other forms of inflammation, we examined its effect on acute contact dermatitis, a form of DTH. This model involves sensitization by oxazolone by epicutaneous immunization followed by challenge with topically applied oxazolone to the ear. The reaction is characterized by local accumulation of $\mathrm{T}$ lymphocytes, monocytes, and neutrophils, leading to an increase in ear thickness. Treatment of elicited mice with $1 \mathrm{mg}$ heparin reduced ear swelling by $67 \%(P<0.005)$, whereas 6 DS-heparin had
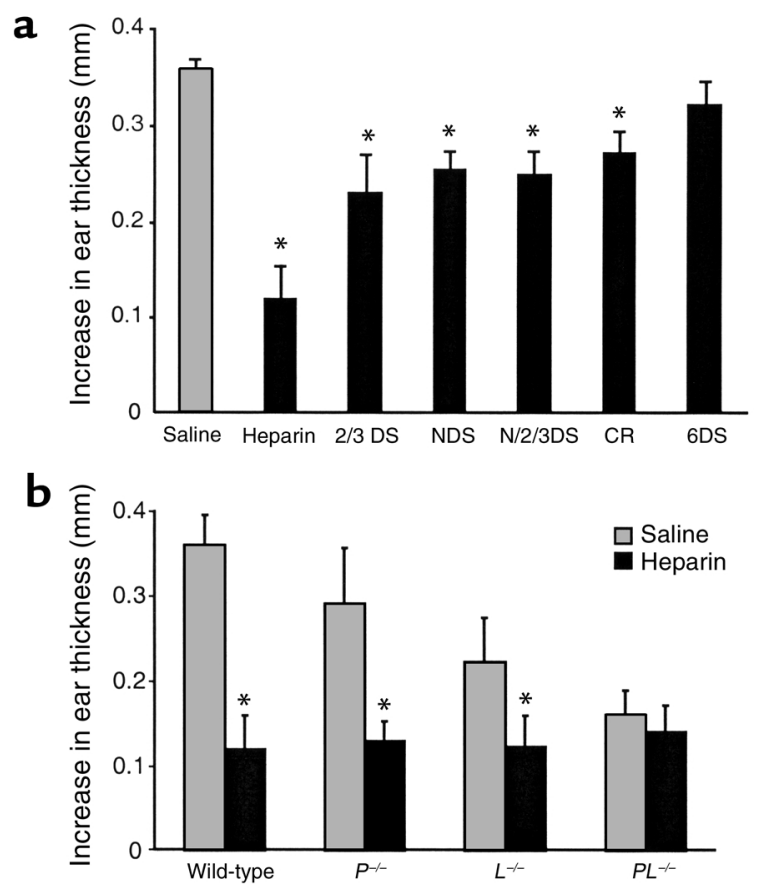

Figure 7

Inhibition of oxazolone-induced ear swelling in sensitized mice. Mice were sensitized to oxazolone and rechallenged by topical treatment of one ear (see Methods). Swelling was measured by ear thickness, and the value obtained from the vehicle-treated control ear was subtracted from those obtained from oxazolone-treated mice. (a) Animals received a single intravenous injection of heparin (1 $\mathrm{mg})$, heparin derivative (1 mg), or saline within 30 minutes after antigen challenge. * Significant difference in ear swelling in the control mice injected with saline (gray bar) versus those that were injected with the heparin derivatives (black bars). (b) Sensitized wild-type and selectin-deficient mice were injected with heparin $(1 \mathrm{mg})$ and rechallenged with antigen as in a. Each bar represents the average value $\pm S D ; n=5-8$. * Significant difference in ear swelling in mice treated with heparin (black bars) versus control mice that received only saline (gray bars). 
no obvious inhibitory effect (Figure 7a). The other heparinoids reduced ear swelling to differing extents, but not as dramatically as heparin $(25-35 \%, P<0.05)$. Of the modified compounds, 2/3DS-heparin had the highest activity (Figure 7a). Frozen sections of the ear biopsies examined by hematoxylin-eosin staining showed large inflammatory cell infiltrates 24 hours after oxazolone application. The intravenous injection of the heparinoids dramatically reduced the number of both mononuclear and polymorphonuclear leukocytes, which correlated with the decrease in ear swelling. The ears of oxazolone-treated mice injected with saline or 6DS-heparin were similarly edematous and had large numbers of infiltrating leukocytes.

Acute contact dermatitis was also induced in $\mathrm{P}^{-/-}, \mathrm{L}^{-/-}$, and $\mathrm{PL}^{-1-}$ mice. All three selectin-deficient mice exhibited impaired reactivity $(20 \%, 38 \%$, and $56 \%$ inhibition, respectively; Figure $7 \mathrm{~b})$. Treatment with heparin (1 mg/mouse) further inhibited the reaction in both $\mathrm{L}^{-/-}$and $\mathrm{P}^{-/-}$mice, but not in $\mathrm{PL}^{-/}$mice. These data confirm that the antiinflammatory effects of heparin are primarily mediated by blocking P-and L-selectin-dependent reactions.

\section{Discussion}

In this report, we have shown that the anti-inflammatory effects of heparin in vivo depend primarily on $\mathrm{P}$ - and L-selectins, and that the 6-O-sulfate group of glucosamine units in heparin is critical for interaction with $\mathrm{P}$ - and L-selectins. Additionally, the 6-O-sulfate group is critical for both anticoagulant and antiinflammatory activity, and 2-O,3-O-desulfation of heparin generates a potent, non-anticoagulant, antiinflammatory agent. These findings suggest that modified heparins may have value as therapeutic agents to block unwanted selectin-dependent reactions.

Much work has been done to find inhibitors to interrupt abnormal leukocyte emigration into tissues during pathological situations (reviewed in refs. 46, 47). SLe ${ }^{\mathrm{X}}$ and various analogs have been studied extensively for this purpose (48-56). Other selectin antagonists include mAb's $(57,58)$ and $\operatorname{SLe}^{\mathrm{x}}$ mimetics $(49-56,59,60)$, as well as recombinant PSGL-1 $(61,62)$. As these selectin inhibitors have various drawbacks, such as narrow cross-reactivity, weak affinity, relatively little selectivity among the selectins, short circulating half-life, great expense to produce in the quantities required for treatment, potential antigenicity, and a very limited track record as intravenous therapeutic agents, the development of these compounds into effective drugs for clinical use has been greatly limited. A search for different classes of glycoconjugates that bind to selectins therefore is worthwhile. Several studies have indicated that heparin and heparan sulfate are ligands for L-selectin and P-selectin and will block their binding to SLe ${ }^{\mathrm{X}}$ and SLe ${ }^{\mathrm{x}}$-related compounds $(17-21,26,28,63)$. Thus, heparin-related structures might be developed as a therapeutic agent for treating undesirable inflammation.

Binding of heparin to L- and P-selectin depends on both sulfation and molecular size $(18,21)$, but detailed structural analysis of the binding oligosaccharide sequence has not been done. $N$-desulfation, $O$-desulfation at $\mathrm{C} 2 / \mathrm{C} 3$, and reduction of carboxyl groups on the uronic acids reduced the ability of heparin to compete for binding and its in vivo anti-inflammatory activities, but the residual activity in these preparations suggests that these groups may not be crucial for binding. In contrast, 6-O-desulfation had a profound effect, indicating an essential role of $\operatorname{GlcNAc}\left(6 \mathrm{OSO}_{3}\right)$ or $\mathrm{GlcNSO}_{3}\left(6 \mathrm{OSO}_{3}\right)$ residues in binding. In rabbits, microinfusion of heparin, dextran sulfate, and chondroitin-6-sulfate reduced the proportion of rolling cells in isolated venules and increased the number of free-flowing cells (64). Interestingly, the dose range used in this earlier study was comparable to the effective dose of heparin required to block adhesion in vitro (Figures 2-4) and leukocyte infiltration in vivo (Figures 6 and 7). These agents also contain sulfate esters at carbon- 6 of glucose, $N$-acetylglucosamine, or $\mathrm{N}$-acetylgalactosamine, respectively, suggesting a common structural determinant. Previous studies showed that Neu5Ac $\alpha 2,3\left(6 \mathrm{OSO}_{3}\right) \mathrm{Gal} \beta 1,4$ (Fuc $\left.\alpha 1,3\right)$ GlcNAc $\beta$ and Neu5Ac $\alpha 2,3 \mathrm{Gal} \beta 1,4(\mathrm{Fuc} \alpha 1,3)\left(6 \mathrm{OSO}_{3}\right)$ GlcNAc $\beta$ in GlyCAM-1 and CD34 interacted with P- and L-selectin in high endothelial venules with higher affinity than did their nonsulfated counterparts (65-67). Thus, the 6-O-sulfated glucosamine residues in heparin may occupy the same site in the selectins that binds the sulfated GlcNAc units in these ligands.

Somewhat unexpectedly, heparin blocked ear swelling in $\mathrm{P}^{-/-}$mice and diminished swelling in non-heparintreated $\mathrm{L}^{-/-}$mice. Catalina et al. reported that the effector phase of contact skin hypersensitivity (CSH) is independent of L-selectin, based on the inability of anti-L-selectin antibodies or L-selectin deficiency to block ear swelling $(68,69)$. The only L-selectin-dependent step in CSH was infiltration of antigen-specific $\mathrm{T}$ cells into the draining nodes after antigen challenge. In the studies reported here, a decrease in ear swelling was observed in the $\mathrm{L}^{-/}$mice (Figure $7 \mathrm{~b}$ ), which presumably reflects a diminished $\mathrm{T}$ cell infiltration into the nodes. The heparin-dependent blockade under these conditions is readily explained by its ability to inhibit P-selectin-dependent infiltration of effector cells (monocytes and neutrophils), since a similar effect was observed using anti-P-selectin blocking antibody in the $\mathrm{L}^{-/-}$mouse (69). In contrast, the ability of heparin to block the $\mathrm{CSH}$ response in $\mathrm{P}^{-/-}$mice is not readily reconciled with previous data indicating the independence of the reaction to L-selectin. Perhaps the difference is related to the concentration and volume of sensitizing/rechallenging hapten (oxazolone). Indeed, Xu et al. reported effects more closely related to our findings using significantly larger doses of hapten for elicitation (70). Under these conditions, nonspecific effector cells may have been recruited, and prior studies from a number of groups have indicated that rolling and infiltration under these conditions have an L-selectin-mediated component $(37,71,72)$. 
As a drug, heparin has wide array of potential pharmacological uses. In the present study, heparin showed strong inhibitory effects in experimental inflammation models. Heparin is known to have inhibitory effects on multiple components of the inflammation cascade, including integrins, cytokines, neutrophilderived elastases, complement activation, and plateletactivating factor- and TNF- $\alpha$-induced lung edema (22). However, to our knowledge this is the first report demonstrating that all of the in vivo anti-inflammatory effects of heparin reflect its action on $\mathrm{L}$ - and P-selectins. This can be explained by the fact that Pand L-selectin-based interactions are a necessary first step in the inflammatory cascade, occurring before the recruitment of integrins, cytokines, proteases, etc. Heparin could also affect downstream steps in the cascade by inhibiting the interaction of chemokines with lumenally exposed heparan sulfate (73).

In clinical practice, heparin is used as an anticoagulant. For it to be used as an anti-inflammatory drug, the risk of inducing bleeding must be abrogated. Partial chemical desulfation or prefractionation of heparin over antithrombin columns showed that the antiinflammatory effects of heparin are independent of anticoagulant activity $(25,28,33,34)$. In contrast, removal of sulfate groups from $\mathrm{C} 2$ of the uronic acids and, more importantly, from $\mathrm{C} 3$ of glucosamine units has a dramatic effect on anticoagulant activity and only slight effects on anti-inflammatory activity properties. However, the processes involved in validating this approach in the clinical setting and getting approval for its general use will likely take a long time. Meanwhile, the currently approved heparin preparations should be investigated for their potential use as antiinflammatory agents at sub-anticoagulant doses. Indeed, recent data on the therapeutic benefits of lowdose heparin in ulcerative colitis (74), in lichen planus, a form of chronic dermatitis (75), and in ischemic conditions like coronary arterial diseases (76) suggest that this approach may meet with success.

\section{Acknowledgments}

This work was supported by grants HL-23594 and HL57345 from the NIH (to J.D. Esko). We thank Yutaka Kariya for the kind gift of 6-O-desulfated and 2,3-Odesulfated heparin standards, Herman van Halbeek and the Glycotechnology Core at the University of California, San Diego (UCSD), for help in interpreting the NMR spectra, Mark Wahrenbrock (UCSD) for performing endotoxin tests on the heparin samples, Richard O. Hynes for providing $\mathrm{PL}^{-/}$mice, Lubor Borsig (UCSD) for help in breeding the selectin-deficient mice, Richard Gallo (UCSD) for providing advice on ACD assays, Nissi Varki for histological assays, and Dzung Le and David Ditto (UCSD) for determining anti-Xa activity of the heparinoids.

1. Springer, T.A. 1994. Traffic signals for lymphocyte recirculation and leukocyte emigration: the multistep paradigm. Cell. 76:301-314.

2. McEver, R.P., Moore, K.L., and Cummings, R.D. 1995. Leukocyte traf- ficking mediated by selectin-carbohydrate interactions. J. Biol. Chem. 270:11025-11028.

3. Lasky, L.A. 1995. Selectin-carbohydrate interactions and the initiation of the inflammatory response. Annu. Rev. Biochem. 64:113-139.

4. Nelson, R.M., Venot, A., Bevilacqua, M.P., Linhardt, R.J., and Stamenkovic, I. 1995. Carbohydrate-protein interactions in vascular biology. Annu. Rev. Cell Biol. 11:601-631.

5. Kansas, G.S. 1996. Selectins and their ligands: current concepts and controversies. Blood. 88:3259-3287.

6. Hynes, R.O., and Wagner, D.D. 1996. Genetic manipulation of vascular adhesion molecules in mice. J. Clin. Invest. 98:2193-2195.

7. Varki, A. 1997. Selectin ligands: will the real ones please stand up? J. Clin. Invest. 99:158-162.

8. Butcher, E.C., and Picker, L.J. 1996. Lymphocyte homing and homeostasis. Science. 272:60-66.

9. Vestweber, D., and Blanks, J.E. 1999. Mechanisms that regulate the function of the selectins and their ligands. Physiol. Rev. 79:181-213.

10. Varki, A. 1994. Selectin ligands. Proc. Natl. Acad. Sci. USA. 91:7390-7397.

11. Rosen, S.D., and Bertozzi, C.R. 1994. The selectins and their ligands. Curr. Opin. Cell Biol. 6:663-673.

12. Leppanen, A., White, S.P., Helin, J., McEver, R.P., and Cummings, R.D. 2000. Binding of glycosulfopeptides to P-selectin requires stereospecific contributions of individual tyrosine sulfate and sugar residues. J. Biol. Chem. 275:39569-39578.

13. Maly, P., et al. 1996. The alpha(1,3)fucosyltransferase Fuc-TVII controls leukocyte trafficking through an essential role in L-, E-, and P-selectin ligand biosynthesis. Cell. 86:643-653.

14. Becker, D.J., and Lowe, J.B. 1999. Leukocyte adhesion deficiency type II. Biochim. Biophys. Acta. 1455:193-204.

15. Homeister, J.W., et al. 2001. The alpha(1,3)fucosyltransferases FucT-IV and FucT-VII exert collaborative control over selectin-dependent leukocyte recruitment and lymphocyte homing. Immunity. 15:115-126.

16. Hayward, R., Nossuli, T.O., and Lefer, A.M. 1997. Heparinase III exerts endothelial and cardioprotective effects in feline myocardial ischemiareperfusion injury. J. Pharmacol. Exp. Ther. 283:1032-1038.

17. Skinner, M.P., Lucas, C.M., Burns, G.F., Chesterman, C.N., and Berndt, M.C. 1991. GMP-140 binding to neutrophils is inhibited by sulfated glycans. J. Biol. Chem. 266:5371-5374.

18. Nelson, R.M., et al. 1993. Heparin oligosaccharides bind L- and Pselectin and inhibit acute inflammation. Blood. 82:3253-3258.

19. Norgard-Sumnicht, K.E., Varki, N.M., and Varki, A. 1993. Calciumdependent heparin-like ligands for L-selectin in nonlymphoid endothelial cells. Science. 261:480-483.

20. Norgard-Sumnicht, K.E., and Varki, A. 1995. Endothelial heparan sulfate proteoglycans that bind to L-selectin have glucosamine residues with unsubstituted amino groups. J. Biol. Chem. 270:12012-12024.

21. Koenig, A., Norgard-Sumnicht, K., Linhardt, R., and Varki, A. 1998. Differential interactions of heparin and heparan sulfate glycosaminoglycans with the selectins. Implications for the use of unfractionated and low molecular weight heparins as therapeutic agents. J. Clin. Invest. 101:877-889.

22. Tyrrell, D.J., Horne, A.P., Holme, K.R., Preuss, J.M., and Page, C.P. 1999. Heparin in inflammation: potential therapeutic applications beyond anticoagulation. Adv. Pharmacol. 46:151-208.

23. Jansen, C.R., et al. 1962. Studies on lymphocytes. II. The production of lyphocytosis by intravenous heparin in calves. Blood. 20:443-451.

24. Sasaki, S. 1967. Production of lymphocytosis by polysaccharide polysulphates (heparinoids). Nature. 214:1041-1042.

25. Sy, M.S., et al. 1983. Inhibition of delayed-type hypersensitivity by heparin depleted of anticoagulant activity. Cell. Immunol. 82:23-32.

26. Borsig, L., et al. 2001. Heparin and cancer revisited: mechanistic connections involving platelets, P-selectin, carcinoma mucins, and tumor metastasis. Proc. Natl. Acad. Sci. USA. 98:3352-3357.

27. Esko, J.D., and Lindahl, U. 2001. Molecular diversity of heparan sulfate. J. Clin. Invest. 108:169-173. doi:10.1172/JCI200113530.

28. Xie, X., et al. 2000. Inhibition of selectin-mediated cell adhesion and prevention of acute inflammation by nonanticoagulant sulfated saccharides: studies with carboxyl-reduced and sulfated heparin and with trestatin A sulfate. J. Biol. Chem. 275:34818-34825.

29. Nagasawa, K., Inoue, Y., and Kamata, T. 1977. Solvolytic desulfation of glycosaminoglycuronan sulfates with dimethyl sulfoxide containing water or methanol. Carbohydr. Res. 58:47-55.

30. Höök, M., Riesenfeld, J., and Lindahl, U. 1982. N-[3H]acetyl-labeling, a convenient method for radiolabeling of glycosaminoglycans. Anal. Biochem. 119:236-245.

31. Wessel, H.P., Hosang, M., Tschopp, T.B., and Weimann, B.J. 1990. Heparin, carboxyl-reduced sulfated heparin, and Trestatin A sulfate. Antiproliferative and anticoagulant activities. Carbobydr. Res. 204:131-139.

32. Shively, J.E., and Conrad, H.E. 1976. Formation of anhydrosugars in the chemical depolymerization of heparin. Biochemistry. 15:3932-3942.

33. Fryer, A., et al. 1997. Selective O-desulfation produces nonanticoagu- 
lant heparin that retains pharmological activity in the lung. J. Pharmacol. Exp. Ther. 282:208-219.

34. Kariya, Y., et al. 2000. Preparation of completely 6-O-desulfated heparin and its ability to enhance activity of basic fibroblast growth factor. J. Biol. Chem. 275:25949-25958.

35. Buchanan, M.R., Boneu, B., Ofosu, F., and Hirsh, J. 1985. The relative importance of thrombin inhibition and factor Xa inhibition to the antithrombotic effects of heparin. Blood. 65:198-201.

36. Guo, Y.C., and Conrad, H.E. 1988. Analysis of oligosaccharides from heparin by reversed-phase ion-pairing high-performance liquid chromatography. Anal. Biochem. 168:54-62.

37. Robinson, S.D., et al. 1999. Multiple, targeted deficiencies in selectins reveal a predominant role for P-selectin in leukocyte recruitment. Proc. Natl. Acad. Sci. USA. 96:11452-11457.

38. Sarkar, A.K., Rostand, K.S., Jain, R.K., Matta, K.L., and Esko, J.D. 1997. Fucosylation of disaccharide precursors of sialyl Lewis $\mathrm{x}$ inhibit selectinmediated cell adhesion. J. Biol. Chem. 272:25608-25616.

39. Lagasse, E., and Weissman, I.L. 1996. Flow cytometric identification of murine neutrophils and monocytes. J. Immunol. Methods. 197:139-150.

40. Capila, I., and Linhardt, R.J. 2002. Heparin-protein interactions. Angew. Chem. Int. Ed. Engl. 41:391-412.

41. Ramos, C.L., et al. 1998. Functional characterization of L-selectin ligands on human neutrophils and leukemia cell lines: evidence for mucinlike ligand activity distinct from P-selectin glycoprotein ligand-1. Blood. 91:1067-1075.

42. Collins, P.W., Macey, M.G., Cahill, M.R., and Newland, A.C. 1993. von Willebrand factor release and P-selectin expression is stimulated by thrombin and trypsin but not IL-1 in cultured human endothelial cells. Thromb. Haemost. 70:346-350.

43. Mulligan, M.S., et al. 1993. Protective effects of oligosaccharides in P-selectin-dependent lung injury. Nature. 364:149-151.

44. Tedder, T.F., Steeber, D.A., and Pizcueta, P. 1995. L-selectin-deficient mice have impaired leukocyte recruitment into inflammatory sites. J. Exp. Med. 181:2259-2264.

45. Frenette, P.S., Mayadas, T.N., Rayburn, H., Hynes, R.O., and Wagner, D.D. 1996. Susceptibility to infection and altered hematopoiesis in mice deficient in both P- and E-selectins. Cell. 84:563-574.

46. Lowe, J.B., and Ward, P.A. 1997. Therapeutic inhibition of carbohydrateprotein interactions in vivo. J. Clin. Invest. 99:822-826.

47. Lefer, D.J. 2000. Pharmacology of selectin inhibitors in ischemia/reperfusion states. Annu. Rev. Pharmacol. Toxicol. 40:283-294.

48. Takada, A., et al. 1993. Contribution of carbohydrate antigens sialyl Lewis A and sialyl Lewis X to adhesion of human cancer cells to vascular endothelium. Cancer Res. 53:354-361.

49. Narasinga Rao, B.N., et al. 1994. Sialyl Lewis X mimics derived from a pharmacophore search are selectin inhibitors with anti-inflammatory activity. J. Biol. Chem. 269:19663-19666.

50. Buerke, M., et al. 1994. Sialyl Lewis ${ }^{\mathrm{x}}$-containing oligosaccharide attenuates myocardial reperfusion injury in cats. J. Clin. Invest. 93:1140-1148.

51. Lefer, D.J., Flynn, D.M., Phillips, M.L., Ratcliffe, M., and Buda, A.J. 1994. A novel sialyl Lewis ${ }^{x}$ analog attenuates neutrophil accumulation and myocardial necrosis after ischemia and reperfusion. Circulation. 90:2390-2401.

52. Maaheimo, H., Renkonen, R., Turunen, J.P., Penttila, L., and Renkonen, O. 1995. Synthesis of a divalent sialyl Lewis x O-glycan, a potent inhibitor of lymphocyte-endothelium adhesion. Evidence that multivalency enhances the saccharide binding to L-selectin. Eur. J. Biochem. 234:616-625.

53. DeFrees, S.A., Phillips, L., Guo, L., and Zalipsky, S. 1996. Sialyl Lewis x liposomes as a multivalent ligand and inhibitor of E-selectin mediated cellular adhesion. J. Am. Chem. Soc. 118:6101-6104.

54. Nguyen, M., Eilber, F.R., and DeFrees, S. 1996. Novel synthetic analogs of sialyl Lewis X can inhibit angiogenesis in vitro and in vivo. Biochem. Biophys. Res. Commun. 228:716-723.

55. Renkonen, O., et al. 1997. Synthesis of a new nanomolar saccharide inhibitor of lymphocyte adhesion: different polylactosamine backbones present multiple sialyl Lewis $\mathrm{x}$ determinants to L-selectin in high-affinity mode. Glycobiology. 7:453-461.

56. Sanders, W.J., Manning, D.D., Koeller, K.M., and Kiessling, L.L. 1997. Synthesis of sulfated trisaccharide ligands for the selectins. Tetrahedron. 53:16391-16422.

57. Chen, L.Y., Nichols, W.W., Hendricks, J.B., Yang, B.C., and Mehta, J.L. 1994. Monoclonal antibody to P-selectin (PB1.3) protects against myocardial reperfusion injury in the dog. Cardiovasc. Res. 28:1414-1422.

58. Lefer, D.J., Flynn, D.M., and Buda, A.J. 1996. Effects of a monoclonal antibody directed against P-selectin after myocardial ischemia and reperfusion. Am. J. Physiol. 270:H88-H98.

59. Skurk, C., Buerke, M., Guo, J.-P., Paulson, J., and Lefer, A.M. 1994. Sialyl Lewis ${ }^{\mathrm{x}}$-containing oligosaccharide exerts beneficial effects in murine traumatic shock. Am. J. Physiol. Heart Circ. Physiol. 267:H2124-H2131.

60. Sanders, W.J., et al. 1999. Inhibition of L-selectin-mediated leukocyte rolling by synthetic glycoprotein mimics. J. Biol. Chem. 274:5271-5278.

61. Borges, E., et al. 1997. The P-selectin glycoprotein ligand-1 is important for recruitment of neutrophils into inflamed mouse peritoneum. Blood. 90:1934-1942.

62. Hayward, R., Campbell, B., Shin, Y.K., Scalia, R., and Lefer, A.M. 1999. Recombinant soluble P-selectin glycoprotein ligand-1 protects against myocardial ischemic reperfusion injury in cats. Cardiovasc. Res. 41:65-76.

63. Zakrzewicz, A., et al. 1997. L-selectin-dependent leukocyte adhesion to microvascular but not to macrovascular endothelial cells of the human coronary system. Blood. 89:3228-3235.

64. Ley, K., Cerrito, M., and Arfors, K.E. 1991. Sulfated polysaccharides inhibit leukocyte rolling in rabbit mesentery venules. Am. J. Physiol. 260:1667-1673.

65. Hemmerich, S., Bertozzi, C.R., Leffler, H., and Rosen, S.D. 1994. Identification of the sulfated monosaccharides of GlyCAM-1, an endothelial derived ligand for L-selectin. Biochemistry. 33:4820-4829.

66. Hemmerich, S., Butcher, E.C., and Rosen, S.D. 1994. Sulfation-dependent recognition of high endothelial venules (HEV)-ligands by L-selectin and MECA 79, an adhesion-blocking monoclonal antibody. J. Exp. Med. 180:2219-2226.

67. Hemmerich, S., Leffler, H., and Rosen, S.D. 1995. Structure of the O-glycans in GlyCAM-1, an endothelial-derived ligand for L-selectin. J. Biol. Chem. 270:12035-12047.

68. Catalina, M.D., et al. 1996. The route of antigen entry determines the requirement for L-selectin during immune responses. J. Exp. Med. 184:2341-2351.

69. Catalina, M.D., Estess, P., and Siegelman, M.H. 1999. Selective requirements for leukocyte adhesion molecules in models of acute and chronic cutaneous inflammation: participation of E- and P- but not L-selectin. Blood. 93:580-589.

70. Xu, J.C., Grewal, I.S., Geba, G.P., and Flavell, R.A. 1996. Impaired primary $\mathrm{T}$ cell responses in L-selectin-deficient mice. J. Exp. Med. 183:589-598.

71. Frenette, P.S., and Wagner, D.D. 1997. Insights into selectin function from knockout mice. Thromb. Haemost. 78:60-64.

72. Forlow, S.B., and Ley, K. 2001. Selectin-independent leukocyte rolling and adhesion in mice deficient in E-, P-, and L-selectin and ICAM-1. Am. J. Physiol. Heart Circ. Physiol. 280:H634-H641.

73. Kuschert, G.S.V., et al. 1999. Glycosaminoglycans interact selectively with chemokines and modulate receptor binding and cellular responses. Biochemistry. 38:12959-12968.

74. Dotan, I., et al. 2001. Low-dose low-molecular weight heparin (enoxaparin) is effective as adjuvant treatment in active ulcerative colitis. An open trial. Dig. Dis. Sci. 46:2239-2244.

75. Hodak, E., et al. 1998. Low-dose low-molecular-weight heparin (enoxaparin) is beneficial in lichen planus: a preliminary report. J. Am. Acad. Dermatol. 38:564-568.

76. Menon, V., Berkowitz, S.D., Antman, E.M., Fuchs, R.M., and Hochman, J.S. 2001. New heparin dosing recommendations for patients with acute coronary syndromes. Am. J. Med. 110:641-650. 